\title{
Effective dose rate evaluation from natural gamma radiation in the region of Ribeirao Preto, SP-Brazil
}

\author{
F. Cavalcante ${ }^{1}$, N.C. Silva ${ }^{2}$, H.L.C. Alberti ${ }^{2}$ and A. De Almeida ${ }^{1}$ \\ ${ }^{1}$ Departamento de Física, Universidade de São Paulo, Ribeirão Preto, \\ Avenida dos Bandeirantes, 14040-901, Brazil \\ ${ }^{2}$ Comissão Nacional de Energia Nuclear - CNEN, Laboratório de Poços de Caldas, \\ Poços de Caldas, 37701-970, Brazil
}

\begin{abstract}
Assessments of natural gamma radiation were done for urban sites in the city of Ribeirão Preto - SP - Brazil, allowing to infer the average annual effective dose value for the population in these areas. The measurements were done using a vehicle with a mobile radioactivity measurement system, Eberline, with a plastic scintillation detector and a Global Position System (GPS), to collect measurements of gamma dose rate and its spatial distribution. Using the national census information, the stored data allowed mapping the radiometric measurements through the ArcGIS software, correlating the geographical coordinates with their respective dose rates. These maps illustrate how effective dose values are distributed within the selected areas and also correlate the collective dose values for these populations. Around 45,000 georeferenced effective dose values, ranging from 12.2 up to $59.8 \mathrm{nSv} / \mathrm{h}$ raised an average value of $0.034 \pm 0.004 \mathrm{mSv}$ /year, which is less than the worldwide average effective dose value of 0.07 $\mathrm{mSv} / \mathrm{year}$ [12] (for outdoor exposures from terrestrial radiation sources) and less than the previous average values found in Brazil for the regions of Poços de Caldas, Guarapari, Andradas, Caldas and Meaípe [2, 10].
\end{abstract}

\section{INTRODUCTION}

The world population is constantly exposed to artificial and natural radiation sources, the latter with a higher contribution most in the total absorbed dose that one can receive in a year. Natural radiation includes those from cosmic rays, cosmogenic radionuclides and terrestrial radiation, responsible for internal and external exposures. While internal exposures are due from the intake of radionuclides through ingestion or inhalation and also due to the ${ }^{40} \mathrm{~K}$ normally existent in the human body, external exposures occur from primordial terrestrial radionuclides, mainly gamma emitters [1]. These last exposures depend on the radionuclide concentrations found in the soil and in building materials, mainly from the ${ }^{238} \mathrm{U}$ and ${ }^{232} \mathrm{Th}$ decay series.

In the assessment of natural terrestrial radiation, gamma spectrometers are usually most used to measure activity concentrations in soil and, using appropriate conversion factors, absorbed dose in air [2-7]. Also, other dosimetric systems have been used for this purpose, such as the thermoluminescent dosimeters [8] and scintillation detectors [9-11].

The levels and effects of natural radiation are assessed and reported by the United Nations Scientific Committee on the Effects of Atomic Radiation (UNSCEAR) [12]. In its latest report, the worldwide average radiation exposure from natural sources was published as $2.4 \mathrm{mSv} / \mathrm{year}$, from which, $0.48 \mathrm{mSv} /$ year is due to external terrestrial radiation (from indoors and outdoors sources), $0.39 \mathrm{mSv} / \mathrm{year}$ due to cosmic and cosmogenic radiation, $1.26 \mathrm{mSv} / \mathrm{year}$ is from inhalation exposure (including radon) and, finally, $0.29 \mathrm{mSv} / \mathrm{year}$ is due to ingestion exposures. Several countries have contributed for this report, but there are not enough data available from Brazil exposures from natural gamma radiation in order to infer an average effective dose to its population, specially for urban groups, since the assessments done before were performed in a few areas and with high natural background. 


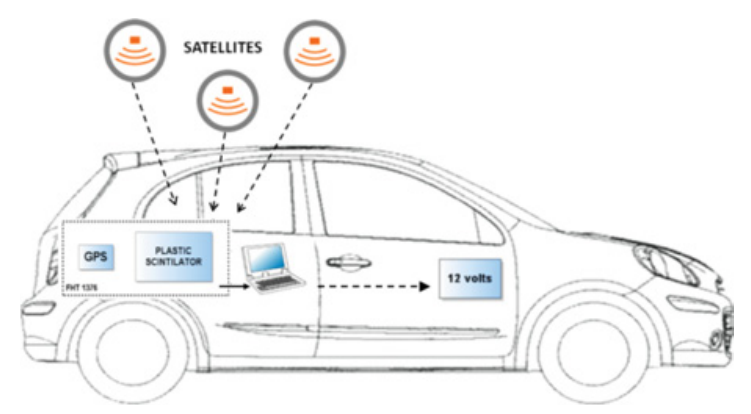

Figure 1. Block diagram representing the set up system composed by satellites, GPS, MobiSys Programm, Computer and plastic scintillator assembled in the vehicle.

Ribeirão Preto is located in São Paulo state, Brazil, being $313 \mathrm{~km}$ far from the state's capital, São Paulo, in the northeast direction ( $21^{\circ} 10^{\prime} 42^{\prime \prime}$ latitude, $47^{\circ} 48^{\prime} 24^{\prime \prime}$ longitude and 544,800 m altitude) on the occidental plateau. The region presents a particular clayed soil called terra roxa (purple land) composed by aluminum and iron oxide [13]. The city has a total area of $650 \mathrm{~km}^{2}$, from which $157,5 \mathrm{~km}^{2}$ are urban areas. It is about $706 \mathrm{~km}$ away from the country capital, Brasilia, and is considered one of the major economic centers in a prestigious surroundings region in the state, for it is not so far from other developed regions in the state and is also close to the Laboratory of Poços de Caldas (LAPOC), from the Brazilian Nuclear Energy Commission (CNEN), in the state of Minas Gerais (MG), with whom this study has a partnership.

The present work intends to obtain the average annual effective dose value for the people living in Ribeirão Preto and to compare it with the already existing natural gamma radiation values for others regions in Brazil, mainly in the urban sites.

\section{MATERIALS AND METHODS}

Natural gamma dose rate measurements were performed through different urban areas in the city of Ribeirão Preto-Brazil, using a mobile radioactivity system (Thermo Eberline /FHT 1376 MobiSys) consisting of a plastic scintillation detector and a Global Positioning System (GPS). These devices are stored in a special case to be easily transported inside a vehicle, along with a computer and an antenna, the system needs to be supplied with an external voltage of $12 \mathrm{~V}$. Once the vehicle starts and three satellite signals are found, gamma dose rate measurements and spatial coordinates are recorded for every second through the program system MobiSys installed in the computer (figure 1). Once dose rate measurements are georeferenced, they can be interpolated in a Geographic Information System (GIS), such as the ArcGIS software, enabling to plot radiometric maps. Also, using the national census information, it is possible to formulate radiometric maps correlating collective dose values for people living in the area.

The mobile system response to effective dose was verified in an outdoor calibration facility that is permanently settled at the Radiological Protection and Dosimetry Institute (IRD) from the Brazilian Nuclear Energy Commission (CNEN), in Rio de Janeiro [14]. For the dose rate measurements the mobile system was installed inside the vehicle at 1 meter from the ground level and, using an average speed of $40 \mathrm{~km} / \mathrm{h}$, scanned the selected areas in the city. These monitored areas were divided in eight parts, far enough from each one, in order to obtain significant data from the total area. Also these parts were chosen for their high population density (except for the university campus region). Each area was formed by a certain number of census sectors, which are small areas determined by the Brazilian Institute of Geography and Statistics (IBGE), to optimize the data sampling [15]. 


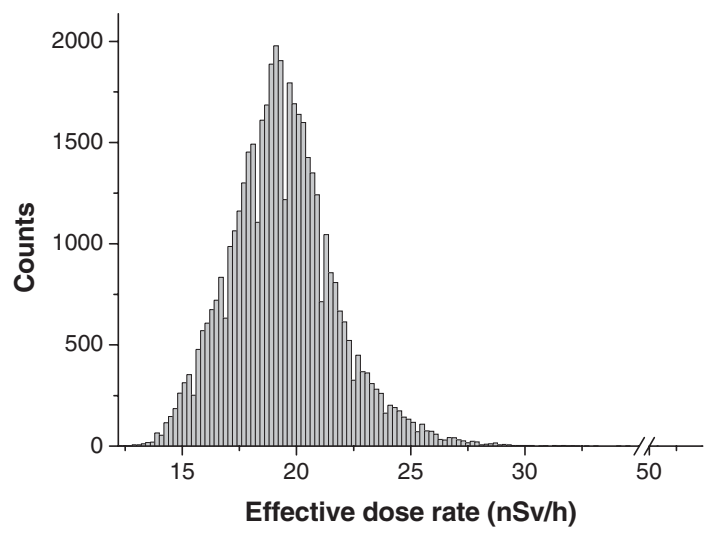

Figure 2. Frequency distribution of all dose rate values collected in the total area studied in Ribeirão Preto.

To estimate the annual effective average dose $\left(\mathrm{E}_{\text {outdoor }}\right)$ value for the selected area [16, 17], due to terrestrial radiation sources, an outdoor occupancy fraction of 0.2 [18] and a Sv/Gy conversion coefficient of $0.7[1,12,18,19]$ were used for the calculation.

$$
\mathrm{E}_{\text {outdoor }}=\dot{\mathrm{D}}_{\text {air }}\left[\frac{\mathrm{Gy}}{\mathrm{h}}\right] \times 8760[\mathrm{~h}] \times 0.2 \times 0.7\left[\frac{\mathrm{Sy}}{\mathrm{Gy}}\right]
$$

The collective effective average dose $(S)$ values and the total annual effective average dose $\left(\mathrm{E}_{\mathrm{p}}\right)$ value for the studied sectors, demand informations collected by the brazilian national census, IBGE [15], related to the number of persons (population) living in each census sector $\left(\mathrm{p}_{\mathrm{i}}\right)$ and the total population studied $\left(\mathrm{p}_{\mathrm{T}}\right)$ to be inferred through the following equations $[10,12]$.

$$
\begin{aligned}
S & =\sum_{\mathrm{i}} \overline{\mathrm{E}}_{1} \times \mathrm{p}_{\mathrm{i}} \\
\mathrm{E}_{\mathrm{p}} & =\frac{\sum_{\mathrm{i}} \overline{\mathrm{E}} \times \mathrm{p}_{\mathrm{i}}}{\mathrm{p}_{\mathrm{T}}} .
\end{aligned}
$$

\section{RESULTS}

According to the latest report from UNSCEAR, the worldwide annual effective dose from natural radiation sources ranges from 1.0 up to $13 \mathrm{mSv}$, and presents an average value of $2.4 \mathrm{mSv}$. From this, about 0.3 up to $1.0 \mathrm{mSv}$ are due to terrestrial radiation (indoor and outdoor), being $0.07 \mathrm{mSv}$ from outdoor average effective doses [12]. In brazilian territory, the nuclear commission CNEN stipulates that the annual effective dose cannot surpass the $1 \mathrm{mSv} / y e a r$ limit [20] above the natural radiation exposure, following international recommendations [21].

About 45,000 georeferenced dose rate measurements were collected within eight different regions in Ribeirão Preto, leading to effective dose rate values varying from 12.2 up to $59.8 \mathrm{nSv} / \mathrm{h}$, as shown in the frequency distribution versus effective dose rate for the total area studied, figure 2 . These values appear in table 1 as a function of each particular region and its population.

Radiometric maps were than formulated using the ArcGIS software, showing the average effective dose values (figure 3) varying from 0.028 up to $0.045 \mathrm{mSv} /$ year and the collective effective dose values (S) averaged for each census sector (figure 4), using the population information (figure 5). As for the 
Table 1. Selected measured areas with their respective population, census sector and radiological characteristics of effective average dose rate, average annual effective dose and average annual effective collective dose.

\begin{tabular}{|c|c|c|c|c|c|c|c|c|}
\hline \multirow[t]{2}{*}{ Selected Area } & \multirow[t]{2}{*}{ Population $^{a}$} & \multirow[t]{2}{*}{$\begin{array}{l}\text { Quantity } \\
\text { of census } \\
\text { sector }^{a}\end{array}$} & \multirow[t]{2}{*}{$\begin{array}{c}\text { Average } \\
\text { Effective } \\
\text { Dose rate } \\
(\mathrm{nSv} / \mathrm{h})^{b} \\
\end{array}$} & \multicolumn{4}{|c|}{$\begin{array}{c}\text { Annual Effective } \\
\text { Dose }(\mathrm{mSv})^{c}\end{array}$} & \multirow[t]{2}{*}{$\begin{array}{c}\text { Annual } \\
\text { Effective } \\
\text { Collective } \\
\text { Dose }^{d}(\mathrm{mSv})\end{array}$} \\
\hline & & & & Average & Max & Min & $\begin{array}{l}\text { Standard } \\
\text { Deviation }\end{array}$ & \\
\hline Centro & 16687 & 38 & 22.847 & 0.040 & 0.045 & 0.036 & 0.002 & 17.12 \\
\hline Vl Tiberio & 18430 & 28 & 20.269 & 0.035 & 0.038 & 0.032 & 0.001 & 23.25 \\
\hline USP & 546 & 1 & 16.004 & 0.028 & 0.028 & 0.028 & 0 & 15.29 \\
\hline Pq Ribeirao & 49929 & 54 & 18.909 & 0.033 & 0.036 & 0.030 & 0.001 & 29.44 \\
\hline Quintino/Simioni & 31802 & 29 & 18.657 & 0.032 & 0.034 & 0.030 & 0.001 & 35.69 \\
\hline Jd Iraja & 15261 & 23 & 20.023 & 0.035 & 0.038 & 0.032 & 0.001 & 22.43 \\
\hline Bonfim Pta & 6444 & 7 & 18.768 & 0.033 & 0.034 & 0.032 & 0.001 & 27.71 \\
\hline Jd Paulista & 17959 & 31 & 20.073 & 0.035 & 0.037 & 0.033 & 0.001 & 19.55 \\
\hline
\end{tabular}

a) Source IBGE 2000; ${ }^{b}$ Measured with the FHT 1376; ${ }^{c}$ inferred from ArcGIS software; ${ }^{d}$ Obtained through equation 2 .

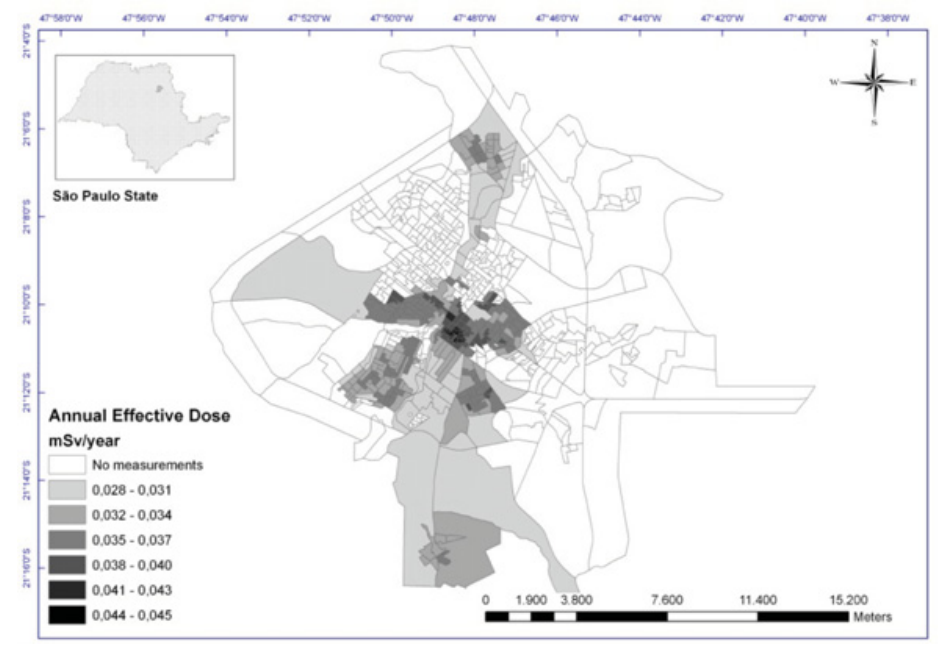

Figure 3. Annual effective dose averaged for each census sector studied.

annual collective effective dose values, an average of $25.62 \pm 9.26$ man $\mathrm{Sv}$ was obtained and the total population effective dose averaged as $0.034 \pm 0.004 \mathrm{mSv} /$ year, about half of the worldwide average value of $0.07 \mathrm{mSv} / \mathrm{year}$.

This average value is also low when compared to values from other studies regarding natural outdoor gamma radiation in Brazilian territory, performed mostly in areas of higher radioactivity levels as Poços de Caldas, Guarapari, Andradas, Caldas and Meaípe [2, 10], where the dose rate can be as high as 88.9 up to $144.5 \mathrm{nGy} / \mathrm{h}[2,10]$. 


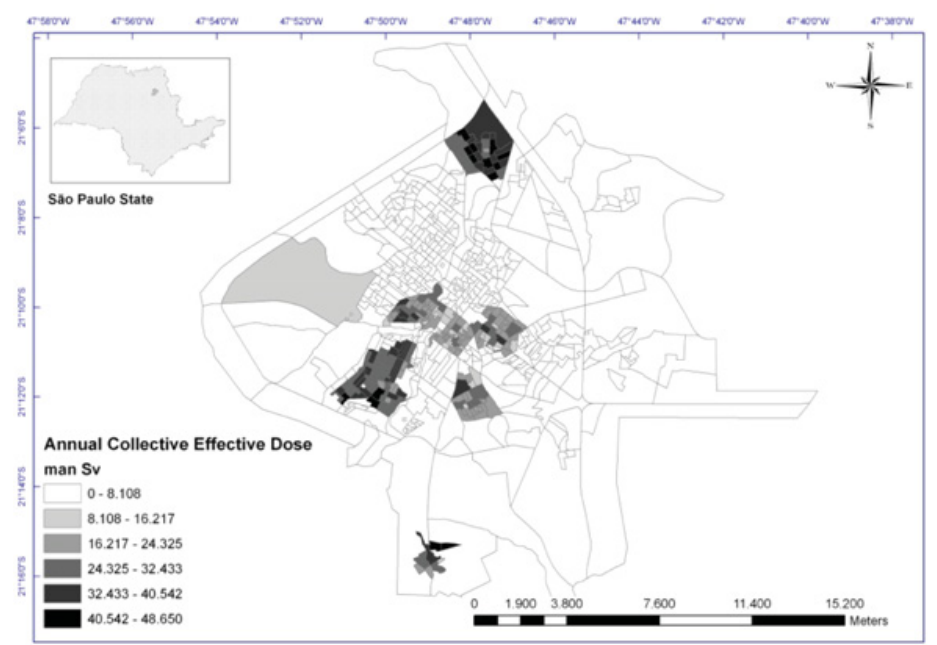

Figure 4. Census sectors map related to annual average collective effective dose.

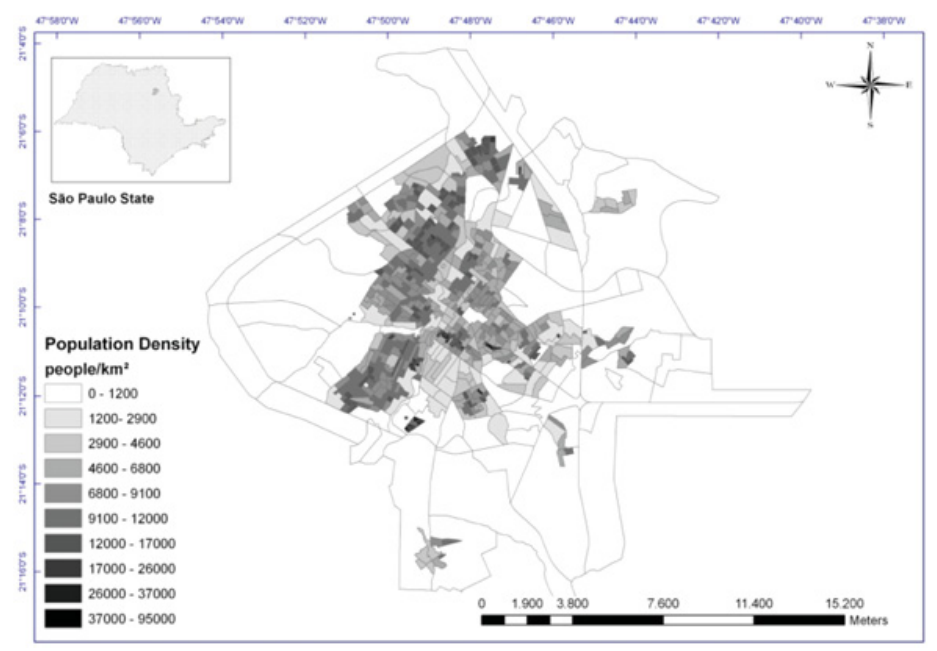

Figure 5. Population density distribution according to each census sector.

\section{CONCLUSIONS}

Radiological data geoprocessing allowed visualization and processing of important informations for the city of Ribeirão Preto, improving the knowledge concerning annual effective dose and collective effective dose levels in the brazilian territory. From the dose rate data collected in accessing different areas in the city, the census sectors showed an average annual collective effective dose value of $25.62 \pm 9.26 \mathrm{man} \mathrm{Sv}$ and a total population average effective dose value of $0.034 \pm 0.004 \mathrm{mSv} /$ year. Although the results found here took into account the contribution of cosmic radiation, the average natural gamma radiation levels found are lower than the world's average value published by UNSCEAR, and also lower than other regions in the national territory, being within the national effective dose limits. 
Knowing that Ribeirão Preto is not an area of high natural background, the average annual effective dose value found in this work can be used as reference to evaluate the levels of radioactivity for other regions in the country.

\section{Acknowledgments}

The authors would like to thank Eder Tadeu Zenun Guerrero from LAPOC for assistance in data collection and the Coordenação de Aperfeiçoamento de Pessoal de Nível Superior (CAPES) for financial support.

\section{References}

[1] Sabol J., Weng P.-S., Introduction to Radiation Protection and Dosimetry (World Scientific, Singapore, 1995) pp. 130-160.

[2] Sachett I.A., "Caracterização da Radiação Gama Ambiental em Áreas Urbanas Utilizando uma Unidade Móvel de Rastreamento”, Doctoral Thesis, Instituto de Biologia Roberto Alcântara Gomes, UERJ, Rio de Janeiro, RJ, Brazil, 2002.

[3] Conti C.C., "Medida de Kerma no Ar e Determinação de Coeficientes de Conversão para Dose Devido à Radiação Gama Ambiental", Master Thesis, COPPE/UFRJ, Rio de Janeiro, Brazil, 1999.

[4] Alencar A.S., Freitas A.C., Radiat Meas, 40 (2005)

[5] Grasty R.L., LaMarre J.R., Radiat Prot Dosimetry, 108 (2004) 215-226

[6] Saghatchi F., Salouti M., Eslami A., Sharafi A., Radiat Prot Dosimetry, 141 (2010)

[7] Papp Z., Radiat Prot Dosim, 141 (2010)

[8] Carneiro J.C.G.G., Betti F., Sanches M.P., Sordi G.M.A.A., Pecequilo B.R.S., "Contribution of Natural Background Radiation to Annual Effective Dose in Different Areas of São Paulo City", $12^{\text {th }}$ International Congress of the International Radiation Protection Association, Buenos Aires Argentina, 19-24 October, 2008.

[9] Yoshimura E.M., Umisedo N.K., Okuno E., Nucl. Instrum. Meth., 487 (2002) 457-464

[10] Silva N.C., Macacini J.F., Alberti H.L.C., "Geoprocessing as a Technical Tool for Radiological Assessment in the Urban Area of Poços de Caldas, MG”, 2009 International Nuclear Atlantic Conference, Rio de Janeiro - Brazil, Septemper 27-October 2, 2009.

[11] Taskin H., Karavus M., Topuzoglu A., Hidiroglu S., Karahan G., J Environ Radioactiv, 100 (2009)

[12] UNSCEAR, United Nations Scientific Committee on Effects of Atomic Radiation, Sources and Effects of Ionizing Radiation, Report to the General Assembly with Scientific Annexes, New York: United Nations (2008)

[13] http://www.brasil.gov.br, accessed on may/2011

[14] Barretto P.M.C., Austerlitz C., Malheiros T. and Løvborg, L., "Radioactive concrete sources at IRD/CNEN, Brazil, for the calibration of uranium exploration and environmental field instruments", IRD/DEX-3/ CNEN, Instituto de Radioproteção e Dosimetria da Comissão Nacional de Energia Nuclear, Rio de Janeiro - Brazil, 1987.

[15] http://www.ibge.gov.br, accessed on may/2011

[16] Turhan S. et al, Radiat. Prot. Dosimetry, February (2011) 1-6

[17] Cetiner M.A., Gunduz H., Ilgar A., Rad Phys Chem, 80 (2011) 704-709

[18] UNSCEAR, United Nations Scientific Committee on Effects of Atomic Radiation, Sources, Effects and Risks of Ionizing Radiation, Report to the General Assembly with Scientific Annexes, New York: United Nations (2000)

[19] Saito K., Petoussi-Henss N. and Zankl M., Health Phy., 74 (1998) 698-796.

[20] CNEN, NN 3.01 Diretrizes Básicas de Proteção Radiológica da Comissão Nacional de Energia Nuclear, Rio de Janeiro, Brasil (2005)

[21] ICRP, Recommendations of the International Commission on Radiological Protection, Publication 60, Pergamon Press, Oxford, 1991 